Tropical Journal of Pharmaceutical Research November 2017; 16 (11): 2659-2665

ISSN: $1596-5996$ (print); 1596-9827 (electronic)

(C) Pharmacotherapy Group, Faculty of Pharmacy, University of Benin, Benin City, 300001 Nigeria.

All rights reserved.

Available online at http://www.tjpr.org

Original Research Article

http://dx.doi.org/10.4314/tjpr.v16i11.13

\title{
Prophylactic effects of triptolide on colon cancer development in azoxymethane/dextran sulfate sodium- induced mouse model
}

\author{
Yizhou Zhou ${ }^{1}$, Li Sun ${ }^{1}$, Lei Cui ${ }^{2}$, Yu Feng ${ }^{1 *}$ \\ ${ }^{1}$ Department of Oncology, ${ }^{2}$ Department of Cardiology, Xuzhou Central Hospital, Xuzhou 221009, China
}

*For correspondence: Email: fengyu889@hotmail.com; Tel/Fax: 0086-18068709060

Sent for review: 9 April 2017

Revised accepted: 8 October 2017

\begin{abstract}
Purpose: To investigate effects of triptolide on colon cancer cell growth and its capacity to prevent tumor development in an azoxymethane (AOM)/dextran sulfate sodium (DSS) mouse model of colon cancer.

Methods: HCT116 cell viability and migration potential were assessed. Control and AOM/DSS-treated mice (with and without triptolide) were analyzed for tumor development. The animals were divided into five groups $(n=5)$. Normal control group was given saline, animals in the untreated control group received AOM and DSS while animals in the treatment groups received 10, 50 and $100 \mathrm{mg} / \mathrm{kg}$ doses of triptolide intraperitoneally alternately for 2 months after AOM and DSS injection.

Results: Triptolide enhanced nuclear material condensation, significantly $(p<0.05)$ increased the levels of cleaved poly (ADP-ribose) polymerase, reduced the levels of pro-caspase-3 and pro-caspase-8 in HCT116 cells. Triptolide also significantly $(p<0.05)$ decreased the expression of $p / k B \alpha$, activated peroxisome proliferator-activated receptor $\gamma$, and markedly reduced the activity of both metalloproteinase-2 and metalloproteinase-9. Treatment of AOM/DSS mice with triptolide significantly reduced adenocarcinoma multiplicity compared to the control group.

Conclusion: Triptolide administration suppresses growth of HCT116 cells and colon cancer development in mice by inhibiting inflammatory responses. Therefore, triptolide has potentials to be developed for colon cancer therapy.
\end{abstract}

Keywords: Cell viability, Condensation, Metalloproteinase, Apoptotic, Triptolide, Adenocarcinoma, Colon cancer

Tropical Journal of Pharmaceutical Research is indexed by Science Citation Index (SciSearch), Scopus, International Pharmaceutical Abstract, Chemical Abstracts, Embase, Index Copernicus, EBSCO, African Index Medicus, JournalSeek, Journal Citation Reports/Science Edition, Directory of Open Access Journals (DOAJ), African Journal Online, Bioline International, Open-J-Gate and Pharmacy Abstracts

\section{INTRODUCTION}

Colon cancer is one of the most commonly diagnosed causes of premature mortality in people of developed countries [1-3]. Tumors present in the lining of the colon are the main cause of deaths associated with cancer in the United States [4]. Adoption of westernized dietary patterns has greatly increased the incidence of colon cancer in Asian people [5].
Cellular apoptosis maintains homeostasis in living organisms by destroying unwanted cells via both extrinsic and intrinsic pathways [6]. In the extrinsic apoptotic pathway, receptors on the cell surface activate caspase-8 [7], whereas in the intrinsic apoptotic pathway, various types of cellular stimuli change the expression levels of members of the $\mathrm{Bcl}-2$ family, leading to the release of cytochrome $c$ [7]. 
The process of cellular apoptosis is evident by changes in cellular morphology, such as altered membrane shape, cell shrinkage, lower mitochondrial membrane potential, nuclear material condensation, and fragmentation of double-stranded DNA $[8,9]$. In various types of carcinomas, such as of the colon, liver, and pancreas, the expression levels of peroxisome proliferator-activated receptor Y (PPARY) increase [10]. Studies have shown that PPARY is associated with the regulation of various processes associated with inflammation [11]. The inflammatory responses induced by nuclear factor-KB (NF-KB) are suppressed by PPARY and its upstream activators. It has been reported that PPARy activation, after exposure to punicic acid, inhibits the inflammation of intestinal tissues in mouse [12]. The expression of genes associated with the inhibition of inflammation is suppressed by PPARY by the targeting of various factors such as NF-KB, p65, and p50 [13].

Natural products isolated during phytochemical investigations have demonstrated promising potential in inhibiting tumor development and progression by stimulating cellular apoptosis $[14,15]$. For example, triptolide, which was isolated during the phytochemical investigation of Tripterygium wilfordii Hook $F$, is a complex diterpenoid molecule [16-18]. Biological investigations of triptolide have revealed its potential as a suppressor of the immune system, an anticancer agent, and a contraceptive [16-18]. Triptolide treatment of cancer cells induces apoptosis via cytochrome $c$ release, damages mitochondria, and suppresses antiapoptotic protein expression [19].

In the present study, the growth inhibitory effects of triptolide on colon cancer cells and on tumor development in an azoxymethane/dextran sulfate sodium (AOM/DSS) mouse model were investigated. The results demonstrate that triptolide treatment of colon cancer cells reduces viability, induces apoptosis, and suppresses tumor development by inhibiting inflammation.

\section{EXPERIMENTAL}

\section{Chemicals}

Triptolide obtained from Sigma-Aldrich Co. (St. Louis, MO) was dissolved in dimethylsulfoxide to prepare the stock solution. Various concentrations of triptolide were prepared at the time of use in experiment. A colonic carcinogen azoxymethane (AOM) was purchased from Sigma-Aldrich. Dextran sulfate sodium (DSS) with a molecular weight of $36,000-50,000$ (cat. no. 160110) was purchased from MP Biomedicals, LLC (Aurora, OH).

\section{Cell culture}

HCT116 colon cancer cells were purchased from Shanghai Institute of Biochemistry and Cellular Biology Chinese Academy of Sciences (Shanghai, China). The cells were cultures in Dulbecco's modified Eagle's medium (DMEM; Gibco Life Technologies, Carlsbad, CA, USA) containing $10 \%$ fetal bovine serum. Antibiotics such as penicillin $(100 \mathrm{U} / \mathrm{ml})$ and streptomycin $(100 \mathrm{U} / \mathrm{ml})$ were also added to the medium. Culture of cells was performed at $37{ }^{\circ} \mathrm{C}$ in an incubator with humidified atmosphere of $5 \% \mathrm{CO}_{2}$ and $95 \%$ air.

\section{MTT assay}

HCT116 and DLD-1 cells after culture in Dulbecco's modified Eagle's medium (DMEM; Gibco Life Technologies, Carlsbad, CA, USA) for $24 \mathrm{~h}$ were incubated with various doses of triptolide for 72 h. MTT (3-(4, 5-dimethylthiazol2yl)-2, 5-diphenyltetrazolium bromide, $5 \mathrm{mg} / \mathrm{ml}$ ) 20 $\mu \mathrm{l}$ was put into each of the well of 96-well plates and then incubation was continued for $4 \mathrm{~h}$ more. Following decantation of medium $150 \mu \mathrm{l}$ of Write in full the first time with the abbreviation in brackets was put into each well of the plate. Absorbance was recorded for each well three times by multi-well reader at a wavelength of 490 $\mathrm{nm}$ to determine the cell viability.

\section{Flow cytometry}

HCT116 cells $\left(2 \times 10^{5}\right.$ cells per $\left.\mathrm{ml}\right)$ after incubation with various doses of triptolide were collected, washed with PBS three times and then treated with binding buffer. Then $5 \mu \mathrm{l}$ each of annexin-V-fluorescein isothiocyanate (FITC) and propidium iodide $(\mathrm{PI})$ were added to cells and the cells were subjected to 15 min incubation under dark atmosphere at room temperature. FACScalibur Flow Cytometer (BD Biosciences, San Jose, CA, USA) was used for the analysis of induction of apoptotic changes in the cells.

\section{Western blot analysis}

HCT116 cells were subjected to incubation with various doses of triptolide for $72 \mathrm{~h}$. The cells were then collected and lysed on treatment with lysis buffer followed by measurement of protein concentration in the supernatant (Pierce, Rockford, IL). The protein separation was achieved using $10 \%$ sodium dodecyl sulfate polyacrylamide gel electrophoresis (SDS-PAGE). Separated proteins were transferred onto the 
nitrocellulose membrane and subsequently incubated with primary antibodies against NF-KB, PPARy, plkBa, iNOS, p50, p65, MMP-2, MMP-9 and $\beta$-actin (all Wuhan Boster Biological Technology, Ltd., Wuhan, China; 1: 1, 000). After incubation the membranes were washed and then incubated with horseradish peroxidaseconjugated secondary antibodies (Wuhan Boster Biological Technology, Ltd.; 1: 10, 000). The complexes formed by interaction of antigen and antibody were analyzed using the enhanced chemiluminescence (ECL) detection system (GE Healthcare Biosciences, Pittsburgh, PA).

\section{Analysis of migration potential}

For the measurement of HCT116 cell migration 24-well Boyden chamber (Corning, Tewksbury, MA) was used. Into the inserts of upper compartment of the Trans well chamber HCT116 cells were put at a density of $5 \times 10^{5}$ cells per 100 $\mu \mathrm{l}$ in the medium devoid of serum. The lower chamber contained $600 \quad \mu$ RPMI 1640 supplemented with $10 \%$ FBS. Migration of the cells was allowed for $72 \mathrm{~h}$ under conditions of 37 ${ }^{\circ} \mathrm{C}$ temperature and in an atmosphere of $5 \%$ $\mathrm{CO}_{2}$. Gentle rubbing was performed to remove the cells that did not migrate using cotton swab. The migrated cells on the lower surface PBS washed and then fixed using methyl alcohol. The cells were then subjected to crystal violet staining followed by measurement of optical density three times independently at $570 \mathrm{~nm}$ wavelength.

\section{Animals}

Institute of Cancer Research strain (ICR) of mice twenty five in number and seven week old were supplied by the Experimental Animal Centre of Zhejiang University (Hangzhou, China). In the animal facility center housing was done under diurnal lighting conditions with $12 \mathrm{~h}$ dark and light cycles and were provided free access to water and food. The temperature in the animal facility centre was maintained $\sim 25{ }^{\circ} \mathrm{C}$ and humidity adjusted to $(55 \pm 10 \%)$. The animals were acclimatized to laboratory atmosphere for seven days before the start of the experiment.

\section{Ethical statement}

The protocol for the study on animals was approved by the Committee on the Ethics of Animal Experiments of the Affiliated Hospital of Academy of Military Medical Sciences (no. MMSA-102/2014). The study was performed according to the guidelines for Ethical Conduct in the Care and Use of Non-human Animals in
Research by the American Psychological Association [20].

\section{Animal studies}

An aqueous solution of dextran sulfate sodium $(1.5 \% \mathrm{w} / \mathrm{v})$ was prepared for inducing colitis in. The animals were divided into five groups of five mice each. The normal control group were given saline, animals in the untreated control group received $A O M$ and DSS whereas animals in the treatment groups received 10,50 and $100 \mathrm{mg} / \mathrm{kg}$ doses of triptolide intraperitoneally alternately for 2 months after AOM and DSS injection. After completion of treatment (2 months) the animals were sacrificed using sodium pentobarbital anesthesia to extract colon. The colon tissues were subjected to histopathological analysis after staining with hematoxylin and eosin (H\&E).

\section{Statistical analysis}

The data obtained were processed using Statistical Package for Social Sciences for Windows, version 17.0 (SPSS, Inc, Chicago, IL, USA). Analysis of the data was performed using monofactorial analysis of variance. The data are presented as mean \pm standard deviation (SD). $P$ $<0.05$ was taken as significant statistically.

\section{RESULTS}

\section{Viability of HCT116 cells is inhibited by triptolide}

Triptolide decreased the viability of HCT116 and DLD-1 cells in a dose-dependent manner. At doses of $10,50,100,150$, and $200 \mu \mathrm{M}$, triptolide decreased HCT116 cell viability by $8,27,53,74$, and $89 \%$, respectively, after $72 \mathrm{~h}$ of treatment (Figure 1). Additionally, the viability of DLD-1 cells was decreased by $11,31,49,68$, and $83 \%$ after the addition of $10,50,100,150$, and 200 $\mu \mathrm{M}$ triptolide, respectively (Figure 1 ).

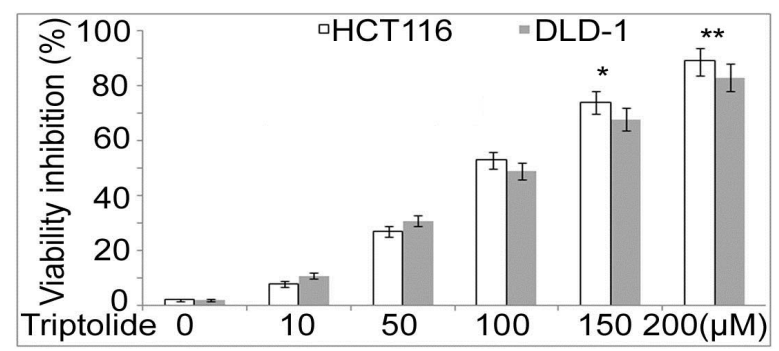

Figure 1: HCT116 and DLD-1 cell viability is reduced by triptolide. Changes in cell viability were determined using an MTT assay and compared to control cultures. Measurements were made in triplicate. ${ }^{*} p<0.05$ and ${ }^{* *} p<0.05$ compared with control cultures 


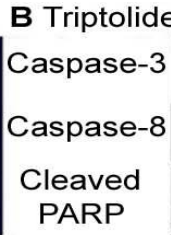

$\beta$-actin

Figure 2: Triptolide induces apoptosis in HCT116 cells. (A) Cells were analyzed at a magnification of $\times 320$ using a Hoechst 33342 stain and fluorescent microscope. (B) Western blot assay results show the expression levels of cleaved PARP, pro-caspase-3, and pro-caspase-8. $\beta$-actin was used as a loading control

\section{Triptolide stimulates apoptosis in HCT116 cells}

Triptolide induced apoptotic changes in HCT116 cells. Increasing the triptolide dose from 10 to $200 \mu \mathrm{M}$ increased the population of HCT116 cells that underwent nuclear material condensation (from 6 to $72 \%$ ) after $72 \mathrm{~h}$ of treatment (Figure 2A). Western blot analysis showed a significant increase in the level of cleaved PARP and a reduction in the expression levels of pro-caspase- 3 and pro-caspase- 8 in HCT116 cells after the addition of triptolide (Figure 2B).

\section{Triptolide reduces NF-KB activity in HCT116 cells}

The expression levels of NF-KB were analyzed in HCT116 cells by western blot analysis. After $72 \mathrm{~h}$ incubation with $200 \mu \mathrm{M}$ triptolide, the expression of $\mathrm{plkBa}$ was significantly decreased, and PPARY activity was increased (Figure 3). No significant increase was observed in the activity of PPARY at either the $10-$ or $50-\mu \mathrm{M}$ doses of triptolide. The levels of $\mathrm{plkB \alpha}$, inducible nitric oxide synthetase (iNOS), p50, and p65 were also decreased after treatment with triptolide.

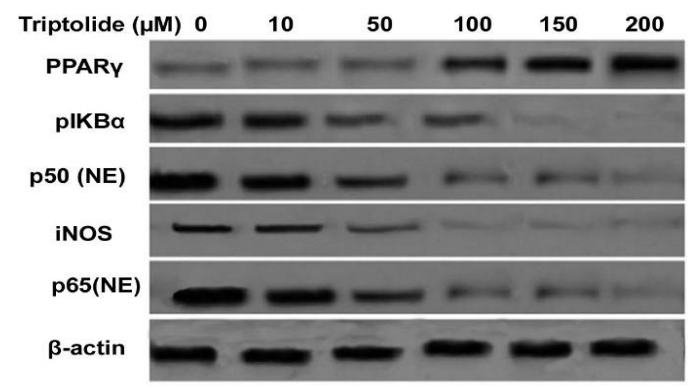

Figure 3: Triptolide treatment of HCT116 cells activates PPARy and downregulates plkBa. Levels of PPARy, plkBa, iNOS, p50, and p65 were measured by western blot analysis. $\beta$-actin was used as a loading control

\section{Migration of HCT116 cells is reduced by triptolide}

Triptolide reduced the migratory potential of HCT
116 cells after $72 \mathrm{~h}$ (Figure 4A). Compared to control cell cultures, the migratory potential of HCT116 cells was reduced significantly after a 72-h incubation with $100 \mu \mathrm{M}$ triptolide. In addition, HCT116 cells treated with $100 \mu \mathrm{M}$ triptolide for $72 \mathrm{~h}$ showed a marked reduction in the activity of both metalloproteinase-2 and metalloproteinase-9 (Figure 4B).

\section{Tumor growth is inhibited by triptolide in an AOM/DSS mouse model}

Untreated control AOM/DSS mice showed markedly high tissue inflammation, as shown in hematoxylin- and eosin-stained sections. On the other hand, treatment of AOM/DSS mice with $100 \mu \mathrm{M}$ triptolide significantly prevented tissue inflammation (Figure 5). The incidence of tumors in the untreated control group was significantly higher than in the triptolide-treated groups. Adenocarcinoma multiplicity in the untreated control group was $3.35 \pm 0.98$, which was reduced to $2.16 \pm 0.56,1.87 \pm 0.46$, and $0.43 \pm$ 0.23 , respectively, in mice treated with 10,50 , and $100 \mathrm{mg} / \mathrm{kg}$ triptolide.

\section{DISCUSSION}

The current study demonstrates the inhibitory effects of triptolide on colon cancer cell growth and on tumor growth in an AOM/DSS mice model. Triptolide reduced the viability of HCT116 cells via apoptotic cell death and prevented tumor growth in mice. Cell death can occur via an apoptotic or non-apoptotic pathway. Apoptosis, or programmed cell death, maintains homeostasis via either an intrinsic or extrinsic pathway [21].

Our study revealed that triptolide reduced HCT116 cell viability through an apoptotic pathway, which was evident by nuclear material condensation. In addition, triptolide promoted the expression of cleaved PARP and decreased the expression of pro-caspase-3 and pro-caspase- 8 in HCT116 cells. It is known that agonists of PPARy inhibit colorectal tumor progression via the upregulation of genes associated with tumor suppression [22].

Trop J Pharm Res, November 2017; 16(11): 2662 
A

Control

Triptolide $(50 \mu \mathrm{M})$

Triptolide $(100 \mu \mathrm{M})$
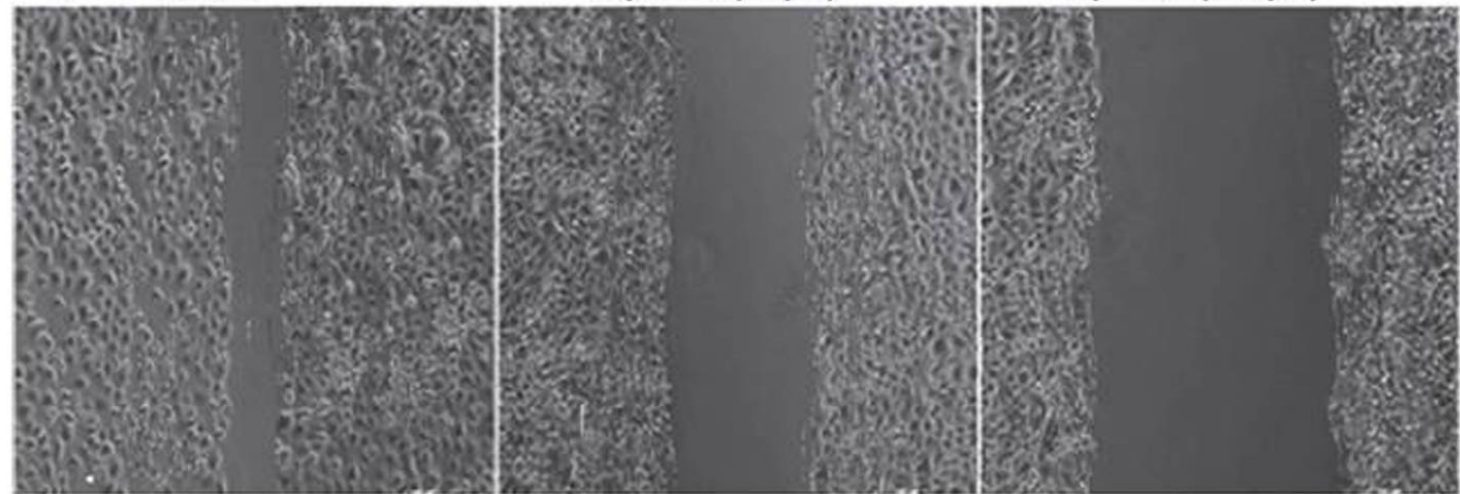

$\mathbf{B}^{\text {Triptolide }(\mu \mathrm{M}) \quad 0}$

10

50

100

150

200

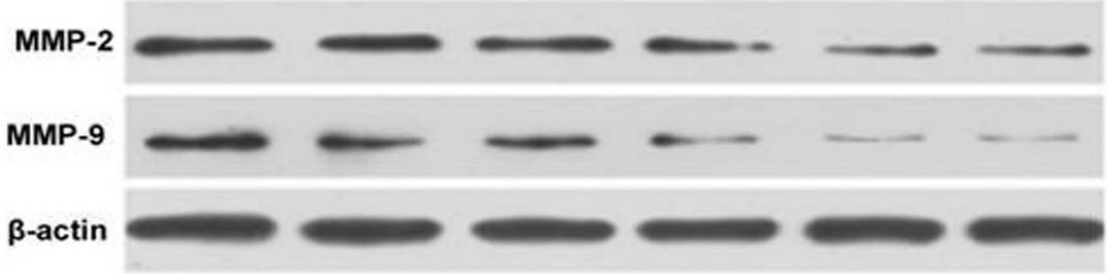

Figure 4: Triptolide reduces migratory potential of HCT116 cells. (A) Cell cultures were scratched with a pipette tip and incubated for $72 \mathrm{~h}$ with either triptolide or solvent (control). The movement of cells into the wounded area was monitored, and photographs were taken. (B) Various doses of triptolide were then added, and the cells were incubated for $72 \mathrm{~h}$ prior to the analysis of metalloproteinase- 2 and metalloproteinase- 9 activity by zymography
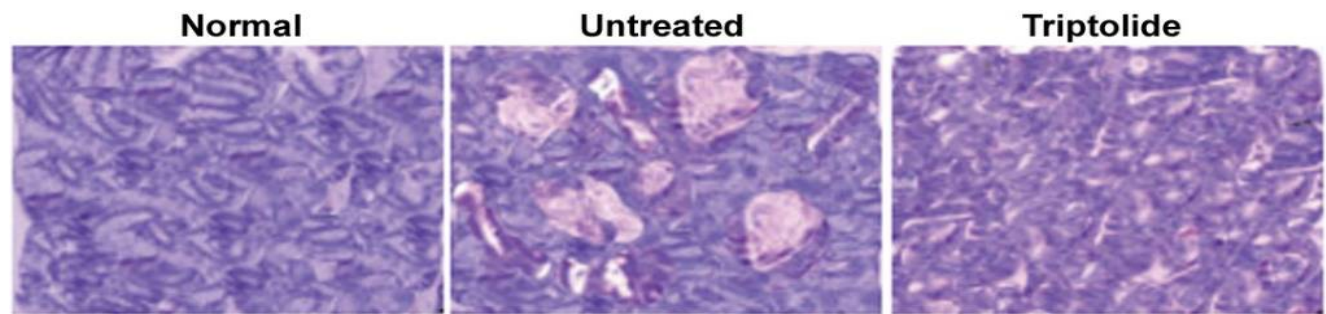

Figure 5: Triptolide treatment of AOM/DSS mice prevents tumor growth. Mice were treated with 10, 50, and 100 $\mu \mathrm{M}$ triptolide for 2 months and then sacrificed for analysis of tissue inflammation and tumor incidence

Such agonists are thus considered to be of great significance for the development of effective chemotherapeutic strategies for colon cancer. Active PPARY inhibits cellular inflammatory processes by targeting gene transcription. Expression of various factors, such as iNOS, cyclooxygenase-2, etc., is associated with the upregulation of inflammatory processes that are regulated by NF-KB [23]. Colon cancer patients are reported to have high levels of active NF-KB, which stimulate tumor progression [24]. Results from the present study show that triptolide enhances PPARY levels and reduces iNOS levels in HCT116 cells. Additionally, metalloproteinases have been shown to play important roles in promoting tumor migration and invasive potential [25].

In HCT116 cells, triptolide increases the expression levels of molecules that promote tumor migration and invasion. The levels of both metalloproteinase-2 and metalloproteinase- 9 were markedly increased after incubation of HCT116 cells with triptolide. A previous study demonstrated that active PPARy caused the inhibition of alimentary canal inflammation; thus, its expression is of significance for the treatment of colon cancer [26]. Our study demonstrated that triptolide treatment of AOM/DSS mice significantly prevented colon tissue inflammation. Moreover, tumor incidence was significantly reduced in these mice after a 2-month treatment with triptolide.

\section{CONCLUSION}

The findings of this study show that triptolide reduces the viability of colon cancer cells via the induction of apoptosis and prevents tumor metastasis in vivo. Therefore, triptolide should be further evaluated as an effective chemotherapeutic agent for colon cancer.

Trop J Pharm Res, November 2017; 16(11): 2663 


\section{DECLARATIONS}

\section{Acknowledgement}

Financial assistance from Department of Oncology, Xuzhou Central Hospital, Xuzhou, China is acknowledged.

\section{Conflict of Interest}

No conflict of interest associated with this work.

\section{Contribution of Authors}

The authors declare that this work was done by the authors named in this article and all liabilities pertaining to claims relating to the content of this article will be borne by them.

\section{Open Access}

This is an Open Access article that uses a funding model which does not charge readers or their institutions for access and distributed under the terms of the Creative Commons Attribution License (http://creativecommons.org/licenses/by/ 4.0) and the Budapest Open Access Initiative (http://www.budapestopenaccessinitiative.org/rea d), which permit unrestricted use, distribution, and reproduction in any medium, provided the original work is properly credited.

\section{REFERENCES}

1. Potter JD. Colorectal cancer: molecules and populations. $J$ natl cancer inst 1999; 91: 916-932.

2. linsalata $M$, Russo F. nutritional factors and polyamine metabolism in colorectal cancer. Nutrition 2008; 24: 302 389.

3. Volate SR, davenport DM, Muga J, Wargovich MJ. Modulation of aberrant crypt foci and apoptosis by dietary herbal supplements (quercetin, curcumin, silymarin, ginseng and rutin). Carcinogenesis 2005; 26 : 1450-1456.

4. Tenesa A, Dunlop MG. New insights into the aetiology of colorectal cancer from genome-wide association studies. Nat Rev Genet 2009; 10: 353-358.

5. Park HJ, Kim MJ, Hae, Chung JH. Apoptotic effect of hesperidin through caspase 3 activation in human colon cancer cells, Sun-c4. Phytomedicine 2008; 15: 147-151.

6. Earnshaw WC, Martins LM, Kaufmann SH. Mammalian caspases: structure, activation, substrates, and functions during apoptosis. Annu Rev Biochem 1999; 68: 383-424.

7. Sun $X M$, MacFarlane $M$, Zhuang J, Wolf BB, Green $D R$, Cohen GM. Distinct caspase cascades are initiated in receptor-mediated and chemical-induced apoptosis. J Biol Chem 1999; 274: 5053-5060.
8. Kaufmann SH, Hengartner MO. Programmed cell death: alive and well in the new millennium. Trends Cell Biol 2001; 11: 526-534.

9. Reed JC. Apoptosis-regulating proteins as targets for drug discovery. Trends Mol Med 2001; 7: 314-319.

10. Dubuquoy L, Rousseaux C, Thuru X. PPARgamma as a new therapeutic target in inflammatory bowel diseases. Gut 2006; 55: 1341-1349.

11. Bassaganya-Riera J, Reynolds K, Martino-Catt S, Cui $Y$, Hennighausen L, Gonzalez F, Rohrer J, Benninghoff $A U$, Hontecillas R. Activation of PPAR gamma and delta by conjugated linoleic acid mediates protection from experimental inflammatory bowel disease. Gastroenterology 2004; 127: 777-791.

12. Bassaganya-Riera J, DiGuardo $M$, Climent $M$, Vives $C$, Carbo $A$, Jouni ZE, Einerhand AW, O'Shea $M$, Hontecillas $R$. Activation of PPARgamma and delta by dietary punicic acid ameliorates intestinal inflammation in mice. Br J Nutr 2011; 106: 878-886.

13. Ricote M, Glass CK. PPARs and molecular mechanisms of transrepression. Biochim Biophys Acta 2007; 1771: 926-935.

14. Thompson CB. Apoptosis in the pathogenesis and treatment of disease. Science 1995; 267: 1456-1462.

15. Lee KH. Anticancer drug design based on plant-derived natural products. J Biomed Sci 1999; 6: 236-250.

16. Zhen $Q S, Y e X$, Wei ZJ. Recent progress in research on Tripterygium: a male antifertility plant. Contraception 1995; 51: 121-129.

17. Tengchaisri $T$, Chawengkirttikul R, Rachaphaew $N$, Reutrakul V, Sangsuwan $R$, Sirisinha S. Antitumor activity of triptolide against cholangiocarcinoma growth in vitro and in hamsters. Cancer Lett 1998; 133: 169175.

18. Hachida $M, L u H$, Zhang $X$, Saito $S$, Furutani $Y$, Matsuoka $R$, Hoshi $H$, Koyanagi $H$. Inhibitory effect of triptolide on platelet derived growth factor- $A$ and coronary arteriosclerosis after heart transplantation. Transplant Proc 1999; 7: 2719-2723.

19. Carter BZ, Mak DH, Schober WD, McQueen T, Harris D, Estrov Z, Evans RL, Andreeff M. Triptolide induces caspase-dependent cell death mediated via the mitochondrial pathway in leukemic cells. Blood 2006; 108: 630-637.

20. American Psychological Association: Guidelines for Ethical Conduct in the Care and Use of Nonhuman Animals in Research. American Psychological Association, Washington, DC, 2012. http://www.apa.org/science/leadership/care/guidelines.a spx.

21. Lorenzo HK, Susin SA. Therapeutic potential of AIFmediated caspase-independent programmed cell death. Drug Resist Updat 2007; 10: 235-255.

22. Yamaguchi K, Cekanova M, McEntee MF, Yoon JH, Fischer SM, Renes IB, Van Seuningen I, Baek SJ. Peroxisome proliferator-activated receptor ligand MCC555 suppresses intestinal polyps in ApcMin/+ mice via extracellular signal-regulated kinase and peroxisome Trop J Pharm Res, November 2017; 16(11): 2664 
proliferator-activated receptor-dependent pathways. Mol Cancer Ther 2008; 7: 2779-2787.

23. Surh YJ. NF-kappa $B$ and Nrf2 as potential chemopreventive targets of some anti-inflammatory and antioxidative phytonutrients with anti-inflammatory and antioxidative activities. Asia Pac J Clin Nutr 2008; 17: 269-272.

24. Rajakangas J, Misikangas M, Paivarinta E, Mutanen M. Chemoprevention by white currant is mediated by the reduction of nuclear beta-catenin and NF-kappaB levels in Min mice adenomas. Eur J Nutr 2008; 47: 115-122.
25. Chiu YW, Lin TH, Huang WS, Teng CY, Liou YS, Kuo $W H$, Lin WL, Huang HI, Tung JN, Huang CY, Liu JY, Wang WH, Wang JM, Kuo HC. Triptolide inhibits the migration and invasive properties of human hepatoma cells. Toxicol Appl Pharmacol 2011; 255: 316-326.

26. Yamamoto-Furusho JK, Penaloza-Coronel A, SanchezMunoz F, Barreto-Zuniga R, Dominguez-Lopez A. Peroxisome proliferator-activated receptor-gamma (PPARgamma) expression is downregulated in patients with active ulcerative colitis. Inflamm Bowel Dis 2011; 17: $680-681$. 